\title{
The role of policy networks in the coordination of the European Union's economic and environmental interests: the case of EU mercury policy
}

Camilla Adelle*, Andrew Jordan and David Benson

Dr. Camilla Adelle (*Corresponding Author)

Centre for the Study of Governance Innovation,

Department of Political Sciences,

University of Pretoria,

South Africa

Email: camilla.adelle@up.ac.za

And

Tyndall Centre for Climate Change Research, School of Environmental Sciences

University of East Anglia

Norwich

NR4 7TJ

United Kingdom

c.adelle@uea.ac.uk

Professor Andrew J. Jordan

Tyndall Centre for Climate Change Research

School of Environmental Sciences

University of East Anglia

Norwich

NR4 7TJ

United Kingdom

Email: a.jordan@uea.ac.uk

Dr. David Benson

Environment and Sustainability Institute,

University of Exeter,

Penryn Campus,

Penryn

Cornwall,

TR10 9EZ

D.I.Benson@exeter.ac.uk

\begin{abstract}
Policy networks can help to coordinate different objectives. The vast literature on network governance often implies that the mere existence of networks will automatically lead to improved coordination. However, much empirical analysis so far has focused on networks within particular policy sectors, which may actually inhibit horizontal coordination across
\end{abstract}


policy sectors. This focus has led to ambiguities regarding the use of networks in practice which this article seeks to help address. By analyzing the role of networks in the coordination of the EU's economic and environmental objectives in the development of its mercury policy, the article demonstrates that policy networks need to span several policy sectors if they are to help reconcile competing policy objectives. Furthermore, certain characteristics of the policy area which contributed to the formation of an inter-sector network in this case are discussed.

\section{Introduction}

Achieving policy coordination is vital to allow competing demands to be reconciled. Without coordination, different policy sectors may pursue their own interests to the detriment of whole system (Peters 1998). Challenges arise when cross-cutting policy issues, such as environmental protection and sustainable development, do not fit neatly into the established remits of individual sectors or departments. Achieving better policy coordination is an age-old challenge for all political systems (Jennings and Crane, 1994). However, there has been a renewed interest in improving coordination in the last decades, in part due to the New Public Management Agenda, leading to a fragmentation of the public sector and increasing autonomy of public agencies (Peters 2013). Increasing demands for coordination have also been driven by the ever-strengthening interconnections between different economic, social and environmental policy areas and the need for 'smarter regulation' (Nilsson et al 2012).

Coordination has been conceptualised in many different ways (Peterson 2013). The literature on EU external relations and international development focuses on policy coherence (Hommels et al 2012; Carbone 2008), while the environment has been addressed by related work under the banner of environmental policy integration (Jordan and Lenschow 2010). Furthermore, coordination can be defined as an outcome and as a process, thereby leading to confusion (Peters 2013). Peters $(1998,296)$ describes coordination as 'an end-state in which the policies and programmes of government are characterised by minimal redundancy [duplication], incoherence [inconsistency] and lacunae [gaps]'. This article, however, mainly considers coordination in terms of its process dimension, defined by Wollmann $(2003,594)$ as 'the attempt to optimize the coherence and consistency of political decisions as well as policy implementation across policies......across actors and stakeholders....across levels'.

One strategy for greater coordination is through using policy networks. According to Peters and Pierre $(2003,595)$, networks 'are more likely to achieve coordination between conflicting interests than either hierarchies or markets' primarily through engendering relational trust and reciprocity. Networks are also thought to be appropriate to coordination in the EU, which has been described as a networked organization (Sbragia 2000). Peters (2003) even suggests that networks may be 'the only real option' for coordinating in procedurally complex, fluid, multilevel and multi-polar systems such as the EU. This approach is therefore useful in assessing the various sectors and institutions of the EU, with their different and sometimes competing policy objectives (Smith 1993, 7).

The sprawling literature on networks, however, still contains many ambiguities regarding their use in practice. In particular, the conditions still have to be specified under which policy networks may enhance or reduce policy making efficiency and legitimacy (Borzel 1998, 267). Drawing on this observation, this article aims at reducing such ambiguity by exploring the conditions in which policy networks coordinated the EU's economic and environmental interests in a real world policy area, namely mercury policy. This case is ideal for examining the relationship between competing EU interests for several reasons. First, it involves an EU policy area with significant economic interests. Mercury has traditionally been used in the chemicals 
industry for the production of chlorine, which in 2003 constituted 55 per cent of the European chemical industry turnover of $€ 580,000$ million. Second, mercury is a highly toxic heavy metal with serious local and transnational environmental impacts. Since the 1970s, mercury has been subject to continuing international and EU environmental policy-making, despite resistance from the chemicals sector who absorbed most costs of implementing these measures. Thus, this policy sector harbours many of the tensions between economic and environmental objectives that have long dogged the EU's pursuit of sustainable development (Baker et al. 1997). Furthermore, the EU's environmental and economic objectives were pitted against each other in a fresh dilemma at the turn of the new millennium when it was realized that the increasing restrictions on mercury use inside the EU had led to a mercury surplus which was sold on the world market, thereby lowering the price and keeping consumption in developing countries buoyant (UNEP 2003). This posed the EU with a dilemma: by selling its surplus mercury on the global market, the EU risked increasing mercury use in developing countries, where it was less regulated and more of an environmental risk. Alternatively, by not selling the mercury the EU would have to store it, presumably indefinitely, and at an unknown cost.

In examining how the EU resolved this coordination problem, this article is structured as follows. It first sets out the characteristics of the EU that render it inherently difficult to coordinate. It then introduces the literature on policy networks to argue that ambiguities surrounding the role of networks in coordination stem in part from the fact that there are two related but distinct types in the literature: (i) sector networks of actors within the same policy area; and (ii) inter-sector networks containing actors from different policy areas. The following section explains how these arguments can be operationalised as an analytical tool to interpret the empirical data, set out in the next section, on how the EU coordinated its economic and environmental interests in the development of its mercury policy. The final section reflects on the implications of these findings on the EU's pursuit of coordination and its governance more widely.

\section{The EU's Internal Coordination Capacity}

\section{The EU's Coordination Challenge}

Several characteristics render the EU inherently difficult to coordinate. First, the multi-level nature of EU governance 'stretches considerably coordination requirements', as it must operate across many vertical levels of governance and different sectors and actors, including several EU institutions (Peters and Wright, 2001, 157). Second, the constantly evolving nature of the EU has expanded the scope, variety and depth of its policy agenda, meaning '[c]oordination was clearly much easier when the agenda was restricted to customs union, parts of energy policy, competition policy, agriculture and commercial policy' (Peters and Wright, 2001, 159). High-level political pledges to 'join up' these and many more sectors in pursuit of more sustainable policy making is merely the most recent (and most complex) stage in this ongoing process. Third, the EU is institutionally and procedurally complex and lacks a clearly defined separation of powers and responsibilities (Kohler-Koch and Eising, 1999). In addition, EU policy processes are relatively open, involving a multiplicity of actors that include representatives of regional and local authorities, as well lobbyists (Kassim 2003a). Finally, 'Brussels is a highly fragmented [policy] universe' (Peters and Wright, 2001, 159). Intra and inter-institutional interactions often take place in a universe of permanent, ad hoc and sub committees. Each institution is internally differentiated and has its own methods, procedures and culture, exercises varying degrees of power, and commands different resources (Kassim 
2003b). This institutional fragmentation of EU institutions leads to strongly pronounced sectorisation (Kassim 2003a).

\section{The Role of Policy Networks}

Various strategies have been employed to pursue greater coordination. While these have been repeatedly categorized, the three fold classification of hierarchies, markets and networks has now become quite conventional (Wollmann 2003; Kooimann 2003). Rather than achieving coordination through prices (markets), or administrative control (hierarchy), networks are considered to build coordination on trust and loyalty (Thompson 2003, 30). Networks are often thought of as having a 'flat' organizational form, in contrast with the vertical stratification of hierarchy (Frances et al 1991). They can comprise multiple actors, including state institutions, organized interests, academics and the private sector (Peters and Pierre 2003, p. 595). The horizontal and largely informal structure of networks provides a multi-lateral forum for 'regular and purposive' relations between actors that create shared expectations and trust (Slaughter 2004). This helps build a functional interdependence among actors who operate cooperatively to problem solve and reach agreement on matters of mutual interest.

Networks offer a powerful analytical tool for studying the EU, and specifically its pursuit of environmental protection and sustainable development, for several reasons. First, it is argued that 'policy networks are the basic unit of European public management' (Metcalfe 2000, 828). In fact, it is difficult 'to describe how the EU works without the metaphor of a network' (Peterson 2004, 120). Second, Peterson $(1995,389)$ refers to networks as 'the most analytically powerful approach on offer'. At the very least, attempting to identifying networks of EU policy actors focuses attention on the stakeholders in the EU policy process. As Richardson $(1996,10)$ argues:

If EU politics is about who gets what, how and when (as surely it is?) then identifying the range of actors involved and trying to see if they can realistically be described as networks is at least the starting point for understanding how the system of making EU policy works.

Third, network analysis fits several EU characteristics. In particular, it allows for the analysis of political systems as fragmented actors rather than a unified whole (Smith 1993, 7). This is particularly useful in the EU with its fragmentation and sectorisation and provides a means of assessing the various sectors and conflicting objectives (Smith 1993, 7).

\section{The coordination capacity of networks}

Crucially, although networks are often presented as a coordinating strategy, there is confusion about whether networks always engender positive outcomes, i.e. if they always have the capacity to coordinate. Börzel $(1998,255)$ argues that this confusion arises from the presence of two distinct strands of the networks literature, each presenting a different view. Marsh and Rhodes (1992), two famous advocates of the 'interest intermediation' school of networks, have proposed a typology to describe different state interest relationships according to their characteristics. These range from closed 'policy communities' to open 'issues networks'. However, this model indicates that policy networks do not easily lead to policy change - surely a prerequisite for policy coordination? This contrasts to the second, 'governance' school, which portrays networks as a specific form of (modern) governance (Kooimann 2003). It assumes that modern societies are characterised by disaggregation and effective problem 
solving capacity is split into sub-systems with limited competences and resources (Börzel 1998). The result is a functional interdependence of public and private actors in policy making which must cooperate to mobilise joint resources to achieve interdependent policy goals (Kooimann 2003).

So how can the same networks be responsible for promoting and inhibiting coordination? Börzel (1998) suggests that there may be two related but different types of network. The state/interest networks are generally conceived to be actors linked in the same policy sector (Peterson and Blomberg 1999). These sector networks, therefore, contain actors with shared values and interests, exhibit a high level of trust and cooperation and achieve solutions which are suitable for their members (Table 1). Perversely, this high level of vertical coordination may inhibit horizontal coordination across sectors (Peters 1998). By keeping outside interests from entering the network, sector networks can shape the agenda to suit their own economic interests rather than the wider public good (Pierre and Peters 2000). Governance or coordination networks, on the other hand, need to be horizontal networks, which span several policy sectors; that is to say they are inter-sector networks. These networks will have low levels of vertical coordination as actors will not necessarily share common values and objectives and so trust and cooperation may be low.

Table 1: Features of sector and inter-sector networks

\begin{tabular}{|l|l|l|}
\hline & Sector network & Inter-sector network \\
\hline Actors & Sector specific & Sector and non-sector specific \\
\hline Values and interests & Shared & Divergent \\
\hline Trust & High & Low \\
\hline Coordination & Vertically strong & Vertically weak \\
& Horizontally weak & Horizontally strong \\
\hline
\end{tabular}

\section{Analytical Approach and Methods}

The above review demonstrates that the EU has characteristics that inhibit its coordination of different policy objectives. One possible strategy for the EU to pursue coordination is through policy networks. However, the presence of networks may not automatically lead to coordination as they must have the capacity to coordinate. We have argued that the coordination capacity of the network (and ultimately how well the EU's different interests are coordinated) depends, in part, on the type of network present in a policy area. Crucially we would expect to see a different level of coordination of the EU's interests depending on whether a sector or inter-sector network dominates the policy area. If a closed sectoral network dominates then we would expect to see a low level of coordination between the EU's competing interests. On the other hand, if an inter-sector network is dominant, higher levels of coordination would occur between the EU's economic and environmental interests. To test these arguments, we explore the role of networks in coordinating the EU's economic and environmental interests through three specific research questions: What type of network was present in the policy area? How well were the EU's economic and environmental interests coordinated? What was the role of the policy network in the coordination of these interests?

To answer these questions we first need to identify what type of network (if any) is present in the policy area. The difficulties of delineating networks in the EU are well noted (Kassim 1994). However, Peterson (1995) argues that the fluidity and institutional complexity of the EU merely make this task difficult but nevertheless 'worth the effort'. We consequently adopt Kickert et al's (1997a, 1.3) definition of networks 'as (more or less) stable patterns of social 
relations between interdependent actors which take shape around policy problems and/or policy programmes'. We then attempt to identify the main actors surrounding the use and regulation of mercury in the EU, the pattern of interactions between these actors, as well as their relative influence on decision making. In the case of a sector network we would expect to find the policy area dominated by actors from one sector (i.e. either the chemicals or the environment sector) and for other actors to either be absent from the policy area or marginalised. In an inter-sector network we would expect from different sectors interacting on a regular basis at meetings and conferences as well as through press releases and written submissions to policy making. In addition, we would expect the different perspectives of the actors feeding into decision making but with no one perspective dominating the policy development.

Second, to answer these specific research questions we also need to evaluate the level of coordination achieved. One approach is to assess the level of trade-offs observed between the different preferences of the actors in the policy outcome, i.e. who gets what. For example, a low level of coordination would be characterized by little trade-off between economic and environmental interests so that (often stronger more concentrated) economic interests dominate decision making and (often weaker and more diffuse) environmental interests are poorly considered. While this is a useful broad-brush approach to assessing the level of coordination as an outcome it tells us little about the level of coordination as a process. Metcalfe's (1994) coordination scale (Figure 1) offers a more nuanced gauge of coordination in its process dimension by grading different descriptions of coordination ranging from loose to more integrated coordination. According to this scale, a low level of coordination between economic and environmental interests would be characterized (as a process) by independent decision making (i.e. excluding the consideration of competing policy interests) or by the exchange of information about interests with little further processing or utilization of this information. Alternatively, a higher Metcalfe Scale score would be characterized, for example, by actors with differing objectives searching for a consensus. (See Appendix One for explanation of how we operationalized the Metcalfe Scale).

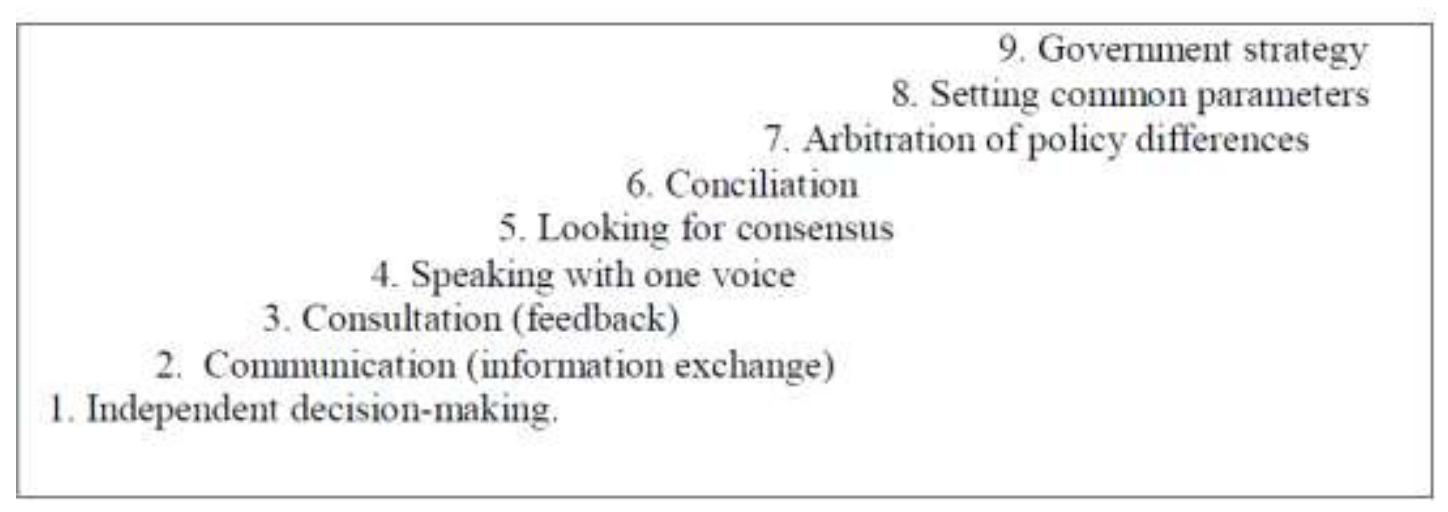

Figure 1 Metcalfe's (1994) Coordination Scale

The following section sets out an empirical account of the development of the EU's mercury policy roughly from the 1950 s to 2006 . However, it focuses in more detail on policy developments (i.e. from 2000 onwards) leading to the agreement on a mercury export ban from the EU. The account follows the changing nature of the policy network from a closed sectoral policy network to a more open inter-sector network. The account is based on data collected from both primary and secondary sources, including official EU documents, academic literature, press releases, NGO reports, and stakeholder consultations. In addition, 15 elite 
interviews were conducted with key actors including officials in the European Commission, EU member states, NGOs, and industry. The interviews were based on a semi-structured format, which allowed for some continuity of questions but also allowed interviewees to give their own personal report of events. The resulting empirical account mainly focuses on EU internal policy dynamics rather than its actions in the parallel international negotiations on a global mercury deal under the auspices of the United Nations Environment Programme (UNEP) (see Andreson et al 2012). In addition, it considers developments involving the European Commission, which is said to be a particularly open EU institution to external stakeholders (Schön-Quinlivan 2012) and where we might most expect to find policy networks.

\section{The Coordination of the EU's Mercury Policy}

\section{Historic Policy Developments: 1950 - 2000}

Traditionally, the European chemicals industry was characterised by strong relations between national chemical industries and the state (Grant et al 1988). However, the chemicals industry was one of the first internationalised sectors (Davis 1984), and it soon began to focus attention on European level lobbying during the 1950s and 60s. The chemicals industry association became a strong industry player in the then EEC, reflecting its huge economic importance, and within it, Euro Chlor was a major actor. The industry was championed by DG III Industry (now by DG Enterprise) and also by those member states which traditionally had the strongest industry presence, i.e. France and Germany. This sector network initially defined the 'policy problem' as a technical one of innovation and increasing production (Duncan 1981). However, new actors introduced competing policy objectives and the policy area became more politicized (Grant et al 1988).

In the 1970s, the EU chemicals sector came under pressure from the rise of the global environmental movement (Grant et al 1988). Particular concern over the long-range movement of heavy metal pollutants, especially in aquatic ecosystems, prompted the search for international governance solutions (UNECE 2006). For example, several regional and international and agreements (such as the Oslo Convention on dumping waste at sea and the Paris Convention on land-based sources of marine pollution) were signed in this period. They laid the foundations for restricting the use and disposal of mercury (Selin and Selin 2006). The EU introduced its first environmental legislation concerning mercury partly as a response to coordinating the implementation of these international conventions (IEEP 2006).

At first these international agreements and EU legislation only lightly impacted on the chemical sector and its economic interests. However, by the mid 1980s, environmental actors had worked to strengthen many of these agreements, as well as create new and geographically broader initiatives (Selin and Selin 2006) thereby increasing the consideration of environmental policy objectives. For example, the Baltic Sea countries in a 1988 HELCOM Ministerial Declaration stated their intention to reduce total discharges of mercury and other hazardous substances by 50 per cent by 1995 . Exporting states with strong chemicals sectors, such as the UK and Germany, then blocked stricter measures (Kellow and Zito 2002). This limited the trade-off of economic interests against environmental ones, at least for the time being. However, at EU level, subsequent daughter directives of the Directive (76/464/EEC) on Dangerous Substances Discharged into the Aquatic Environment set standards controlling emissions of particular substances, including mercury discharges from chlor-alkali plants (82/176/EEC). The chlor-alkali industry was forced to introduce alternative, less polluting processes at substantial cost (IEEP 2006) and for the first time economic interests were tradedoff against environmental objectives. 
Despite this proliferation and upgrading of international and EU environmental regulation, and the subsequent cost to industry of cleaning up their act, the chemicals sector had not completely lost control of the policy area. They were able to (successfully) resist more ambitious environmental states such as Sweden, Denmark and the Netherlands who desired further trade-offs of economic interests against higher levels of environmental protection. For example, in 1990 the parties of the OSPAR Convention for Protection of the Marine Environment (which replaced the Oslo and Paris Conventions) only agreed on a 'recommendation', which was not legally binding, to phase out the use of mercury in chloralkali plants by 2010 (interviews 15; 7). This was in the face of pressure from countries such as UK, France, Germany and Spain as well as Euro Chlor. Euro Chlor claimed that, phasing out old plants before the end of their life span was not economically justifiable as it would involve an investment of $€ 3.5$ billion (interview 14; Euro Chlor 2004).

Environmental actors attempted to introduce a more effective phase out date of 2007 through the Integrated Pollution Prevention and Control Directive but failed due to a political compromise which allowed 'competent authorities' within member states to decide the specific permitting conditions for chlor-alkali plants (interview 3; European Commission 2005b). Eventually, in 1999, after an unsuccessful attempt to negotiate a later phase out date with OSPAR parties, Euro Chlor organized a voluntary agreement with the industry to phase out mercury use by 2020 (interviews 14; 15; Euro Chlor 2004). The environmental actors had therefore succeeded in bringing about emission controls on mercury, but the chemicals sector managed to retain the right to use mercury, albeit at lower emission levels. This crucially allowed mercury plants to reach the end of their life span and was therefore less damaging to the sector's economic interests - but with some cost to achieving environmental objectives.

\section{The Mercury Export Ban: 2001-2006}

By the new millennium, the EU, however, was beginning to face up to a new phase in its 'mercury problem': What would it do with its large surplus of mercury as it phased out the use of mercury in its chlor-alkali plants? The remaining half of the EU's chlor-alkali plants that still used mercury technology was due to be phased out by 2020 which would lead to 1000 tonnes of additional mercury being placed on the world market from the EU every year up to that point. This was in the context of a rising global concern (specifically from the Arctic Council, the Swedish government, as well as the UNEP) about global heavy metal pollution (Selin and Selin 2006; interviews $3 ; 15 ; 8$ ) as well as a growing understanding internationally of the dynamics of the global mercury markets (Maxson 2004; UNEP 2003). Consequently, acting on the demand of various environmentally minded member states (Interview 7; Swedish EPA 2003), in 2001 the European Council invited the Commission to present a strategy to combat this new 'mercury problem'.

Actors from both the chemicals and environmental sectors then mobilized to provide input into the 'Mercury Strategy'. A substantial amount of information was exchanged between them through press releases, open letters and meetings - even before the Commission launched its official stakeholder consultation - which was relatively wide and open (e.g. Euractiv 2003; Greenpeace 2003; Ministry of Environment Sweden 2004; Euro Chlor 2003). In addition, DG Environment organized a stakeholder workshop, which was attended by over 100 participants, including member states, NGOs, industry and scientists (European Commission 2005b; Interview 1). This was preceded by a two-day conference organized by the Swedish Environmental Protection Agency (Nordic Council 2004).

Interactions between the chemicals and environmental sectors do not, however, indicate a consensus on the 'correct' policy solution. Many member states (e.g. Austria, Denmark, 
Finland, Netherlands, Sweden) and environmental NGOs (e.g. Greenpeace, Natural Resource Defense Council and the Mercury Policy Project) expressed their support for a mercury export ban (European Commission 2005b). Sweden in particular, submitted a report on possibilities for permanent storage (Swedish EPA 2003). In contrast, Euro Chlor and several member states with strong chemicals industries (e.g. the UK, Germany and France) questioned the effectiveness of a unilateral EU export ban (European Commission 2005b; Euro Chlor 2004; Interviews 1; 14). DG Enterprise was also skeptical about unilateral action (Interviews 1; 3; 15). This generated a great deal of discussion both inside and outside the Commission, which lasted long after the official consultation and included informal meetings between DG Environment and environmental NGOs as well as Euro Chlor. However, these issues would not be resolved until the next (legislative) phase of the policy making process.

When the Mercury Strategy was eventually published in January 2005 its rationale appeared to be influenced by a sense of global environmental responsibility on the EU's mercury surplus (European Commission 2005a, p.1). The strategy proposed various measures to reduce the EU's role in the global mercury cycle: including banning mercury exports by 2011; storing mercury surpluses; and supporting global action to address the mercury problem (European Commission 2005c). The Strategy was published in time for the UNEP Governing Council in February 2005, which was to discuss the 'mercury problem', and provided the basis of the EU's position (European Commission 2005d; EEB et al 2005a). The strategy elicited a surprisingly high level of tacit agreement among the different actors outside the Commission (Interviews 2; 9). Disagreement centered not on the need for a ban but mainly on how, and when, the ban should be implemented (Council of the European Union 2005; interviews 2; 9; EEB et al 2005b). Euro Chlor again warned that a unilateral EU export ban was unlikely to solve the global mercury problem (Euractiv 2006). However, it was not against the export ban per se, rather it urged more international action on the issue.

Much to the frustration of environmental NGOs, the subsequent legislative proposal for the mercury export ban stalled due to continued internal wrangling within the Commission (EEB et al 2006a; EEB et al 2006b). Questions were again raised by DG Enterprise over the effectiveness of the export ban (interviews 2; 3). Agreement was only eventually reached when it became obvious that economic impacts would be negligible (interview 3 ). Therefore, in the face of limited resistance from its main constituency (i.e. Euro Chlor), DG Enterprise endorsed the ban. Meanwhile, discussions between DG Environment and Euro Chlor on storage plans for decommissioned mercury (interview 14) led to a proposal for a regulation enforcing the storage of mercury (European Commission 2005c) but leaving industry and authorities in concerned member states to decide where (and how) this would take place (interview 2). Legislative proposals to ban mercury export by 2011 (European commission 2006a) were adopted by the Commission on 26 October 2006 in time to be presented as the centre piece for an international conference on mercury policy organized by DG Environment.

\section{The Coordinating Role of the Policy Network}

\section{What Type of Network was Present?}

The empirical account shows that a gradual transformation in network form occurred over time. During the early development of the EEC, mercury policy area was manifestly controlled by a sector network comprised of similar actors with shared values and interests. Our research suggests that this network consisted almost exclusively of representatives from Euro Chlor, DG Industry (now Enterprise) and the industry minister from member states with large chemical industries; primarily France and Germany. This network remained relatively stable in terms of 
its composition between the 1950s and early 1970s but external challenges then began to reshape it towards a more inter-sector network form. Over a period of three decades, influential environmental actors, such as the Swedish Environmental Protection Agency, DG Environment and the environmental NGOs, worked to gradually open up this closed sector network to become more inclusive. By the dawn of the new millennium these new actors could be considered part of such a network because they met regularly at EU and international conferences, shared information (that is to say resources) with each other as well as with EU institutions, and influenced the decision-making. One example comes from the development of the Mercury Strategy, which involved industry, governments, scientists, NGOs and EU actors. Furthermore, environmental actors eventually became so central to this policy network that chemicals policy became a joint responsibility between DG Enterprise and DG Environment.

\section{How well were Economic and Environmental Interests Coordinated?}

It was predicted, earlier in this article, that sector networks would provide greater vertical coordination capacity than inter-sector networks, which would be more horizontally stronger at sectoral coordination. This pattern appears replicated in the data as, prior to the 1980s, economic interests were given precedence in the policy debate and little or no conscious trading-off occurred took place with other policy objectives. But during the 1980s and 1990s, these economic interests began to be traded-off against environmental policy objectives as the inter-sector network developed. However, economic interests were still considered important enough to trade against some, albeit a lesser amount, of concern over environmental quality. In particular, in the 1990s the chemicals sector kept control of the phase out date of mercury technology from their plants. In addition, in the recent policy development since 2000 the chemicals sector retained some determination over storage options thus avoiding the most expensive and restrictive choices. In general, however, in the recent policy developments environmental actors had significant success in their support for a mercury export ban. Therefore, it is apparent that the coordination (as an outcome) achieved between the EU's economic and environmental interests has increased over time - both economic and environmental considerations were evident in the final legislation but no one set of interests got all their demands met to the expense of the consideration of other interests.

Furthermore, according to the Metcalfe Coordination Scale, the early phase of the EU chemicals policy in the 1970s and 1980s indicates the lowest form of coordination between the EU's economic and environmental and interests, that is to say level one - 'independent policy making' in different sectors. However, more detailed analysis of the EU's most recent policy developments indicates far high levels of coordination. Level two coordination ('information exchange') was achieved through discussions between the actors, either bilaterally or in regular conferences and workshops. Level three coordination ('consultation') was reached because feedback (that is to say a two way flow of information between the Commission and stakeholders) on certain issues was sought. The information gathered through these low levels of coordination with stakeholders then fed into the higher levels of coordination which took place mainly within the Commission. However, stakeholders still had a chance to influence the proceedings through access to 'their' DG officials. Thus, levels four and five ('speaking with one voice' and 'seeking consensus') were achieved when the proposals were adopted by the Commission in the face of limited opposition from key stakeholders. All DGs had to agree the proposals before this could happen. This involved lengthy discussions between DG Environment and DG Enterprise on the effectiveness of a ban on world trade as well as between DG Environment and Euro Chlor on storage options. However, without apparent acrimony between these actors, discussions were maintained and 
an agreement which satisfied all sides was eventually reached. Therefore, higher levels of coordination such as level six ('conciliation') and level seven ('arbitration') were not called for.

\section{What was the Role of the Policy Network in the Coordination of these Interests?}

Prior to the 1980s, a sectoral chemicals network championing their own economic interests kept other issues, such as environmental objectives off the agenda and resulted in low level coordination between the EU's economic and environmental interests. However, the gradual formation of an inter-sector network up to the start of the new millennium facilitated the eventual high level of coordination witnessed between the EU's economic and environmental interests. This inter-sector network ensured that all the relevant EU policy objectives were considered in the development of the Mercury Strategy. In this way, members of the network from the relevant policy sectors shared information and problem-solved to reach a policy solution that was broadly acceptable to all. The EU was subsequently able to resolve any potential conflict between its economic interests and its economic and environmental interests. The resulting coherence between its economic and environmental interests enabled the EU to agree a ban on the export of its own mercury surplus, despite a cost to industry.

\section{Conclusions: Implications for EU Governance}

The EU finds itself under increasing pressure to coordinate as modern policy problems, such as climate change, biodiversity loss, food security and global poverty, are no longer confined to a single sector, organization or geographical area. The EU has searched long and hard for new ways to meet these coordination needs, including those relying on networks (Jordan and Schout 2006). In this article, we drew on the policy networks literature to demonstrate that the type of policy network present in a particular policy area plays an important role in the EU's capacity to coordinate and ultimately reconcile its competing interests. We have demonstrated that, in the case of EU mercury policy, while the initial (chemicals) sectoral network led to the EU's economic interests dominating decision making, the eventual formation of an inter-sector network helped to reconcile the EU's economic and environmental interests. The inter-sector network provided a platform on which the various actors with a stake in the policy area, but often with very different objectives, could reconcile their positions through regular interactions and ultimately problem solving.

This finding has important implications for the pursuit of coherence and governance in the EU, especially if, as some authors argue, sector networks are more likely to self-steer, and indeed self-form, than inter-sector networks (Jordan and Schout 2006). Traditionally networks have been presented as 'autonomous' and 'self-organizing' that is to say self-steering (Rhodes 1996, 659 ) by the 'interest mediation' school. This understanding of networks may well be true in homogeneous sectoral networks where resource dependencies and shared values facilitate network actors to 'identify their mutual inter-dependence, formulate and implement shared strategies' (Schout and Jordan 2005, 201). The implication is that in the presence of networks, coordination requires little or no central hierarchical steering (ibid). There are also authors, however, who question the ability of networks to self-steer and satisfactorily govern crosscutting policy problems where the values of actors may be very different. Schout and Jordan $(2005,17)$ warn that in these circumstances 'it is quite conceivable that some much-needed networks may never self-steer (that is to say that they simply will not form at all), or they may evolve in ways that are ineffective'. 
In the case of EU mercury policy, an inter-sector network did eventually form and to a certain extent even self-steered; as evidenced by the organization of conferences and the formation of the Zero Mercury Campaign. However, characteristics of the policy area are likely to have contributed to this. First, the science of the policy problem was not in dispute. Although industry and environmental actors disagreed on the level of safe mercury use in chlorine production, neither disputed its toxicity. Indeed, both groups favoured the phasing out of mercury use and only the timing was disputed. Second, the formation of an inter-sector network took time. The sector network opened up into an inter-sector network over the course of at least three decades. Networks take time and resources to develop, especially those that span international and ideological borders (Kellow and Zito 2002). NGOs often complain that they lack the resources to participate on equal terms with industry lobbyists (Mazey and Richardson 1993). Without the dedicated and significant funding of the Zero Mercury Campaign, it is doubtful if NGOs would have maintained influence within the policy network. Third, the economic cost to both phasing out mercury and its indefinite storage were low, as long as compromises were made on phase outs and storage options. Many other policy areas will be too controversial, in that they will not contain win-win solutions and cost tradeoffs for actors to exhibit the coordination characteristics commonly ascribed to networks, such as trust and shared resources.

When networks do not self-steer, the literature suggests network management to improve the cooperation between the actors involved (Jordan and Schout 2006; Kickert et al 1997a; Metcalfe 2000). However, the EU has been criticized for its non-engagement in network management, especially given its current reliance on network governance approaches (Jordan and Schout 2006). In addition, it is not immediately obvious in the EU multi-level governance system who should manage networks. Although networks are now 'ubiquitous' (Peters 2013, 578 ) it does not mean that they are the only answer to the EU's coordination problems. The EU should probably be more skeptical about the coordinating capacity of networks in its tackling of complex cross-cutting issues such as the environment. Despite the prevailing interest in networks, alternative strategies are available, that is to say markets and hierarchy, and different ways to combine them. However, rather than moving away from network and market-based mechanisms altogether, it may be that it is 'the mix that matters' (Rhodes 1997, 40). Combining networks with more hierarchical approaches may be more effective than a sole reliance on self-steering networks.

Finally, although coordination is often presented as 'the eternal problem....in governance' (Perri 6 et al 2002, 9), it is worth considering whether perfect coordination is actually achievable or even desirable. Jordan and Halpin (2006) argue that more coherence in one area may come at the cost of incoherence elsewhere. Therefore, while a lack of coordination may simply reflect poor policymaking, it is important to acknowledge the practical limitations on policy harmonization. Indeed, despite the abundant rhetoric on the pursuit of environmental objectives, it is not the only high level objective that the EU has made ambitious commitments to. Other competing objectives, which are not necessarily compatible, or perceived to be compatible, with a high level of environmental protection must be traded-off against it and each other. Which objective is the strongest at any one time will reflect changes in wider political priorities.

\section{References}

Andresen, S., K. Rosendal, and J.B. Skjærseth, 2012. Why negotiate a (binding) mercury convention?' International Environmental Agreements, DOI: 10.1007/s10784-012-9198-6. 
Baker, S., M. Kousis, D. Richardson, and S. Young. 1997. Introduction: the theory and practice of sustainable development in the EU. In S. Baker, M. Kousis, D. Richardson and S. Young (eds). The politics of sustainable development: theory, policy and practice within the EU London: Routledge, 91-106.

Börzel, T. 1998. Organising Babylon: on the different conceptions of policy networks. Public Administration 76, 253-273.

Carbone, M. 2008. Mission impossible: the European Union and policy coherence for development. Journal of European Integration 30: 323-42.

Council of the European Union 2005. Draft council conclusions. Environment Council. 14 March. Brussels.

Davis, L.N. 1984. The corporate alchemists: The power and problems of the chemical industry. London: Temple Smith.

Duncan, S. 1981. Chemical industry in its historical context. In D.H. Sharp, and T.F. West (Eds.) The chemical industry. Chichester: Ellis Horwood Limited, 40-61.

Euractiv 2003. How Can the Chlorine Industry be Environmentally Responsible? Press Release. 27/02/03.

Euractiv 2006. Commission presents Mercury Strategy. News item published 1/02/05. Available at: $<<$ http://www.euractiv.com/climate-environment/commission-presents-mercurystrategy/article-134881 >>. Last accessed 06/02/2014.

Euro Chlor 2003. Industry position on mercury management. Press Release 27/02/03.

Euro Chlor 2004. Euro Chlor's Contribution to the European Commission's Consultation Document on the Development of an EU Mercury Strategy. Report submitted to the European Commission.

Euro Chlor. 2005. Facts and Figures. <<http://www.eurochlor.org/factsfigures $>>A c c e s s e d$ 27/06/07

European Commission. 2002. Report from the Commission to the Council concerning mercury from the chlor-alkali Industry. COM (2002) 489.

European Commission. 2005a. Commission proposes strategy to deal with mercury pollution including a ban on exports. Press Release: IP/05/114, 31 January. Available at: <<http://europa.eu/rapid/press-release IP-05-114 en.htm >>. Last accessed 23/08/2013.

European Commission. 2005b. Communication from the Commission to the Council and the European Parliament on Community Strategy Concerning Mercury. Extended Impact Assessment. SEC (2005) 101.

European Commission. 2005c. Community strategy concerning mercury. COM (2005) 20.

European Commission. 2005d. Commission Proposes Strategy to Deal with Mercury Pollution Including a Ban on Exports. Press Release: IP/05/114 (31/01/05).

European Commission. 2006a. Proposal for a regulation on the banning of exports and the safe storage of mercury. COM (2006) 636.

European Commission 2006b. Environment: Commission proposes ban on EU mercury exports. Press Release. IP/06/1481. 26/10/06. Available at: <<http://europa.eu/rapid/pressrelease IP-06-1481 en.htm >>. Last accessed 06/02/2014.

European Council 2005a. Presidency Conclusions of the European Council on guiding principles for sustainable development. 16-17 June 2005, Brussels, 18 June.

EEB et al. 2005a. Zero Mercury: Key issues and policy recommendations for the EU Mercury Strategy. Brussels. Zero Mercury Campaign.

EEB et al. 2005b. Environment Council makes positive but cautious steps towards ending mercury pollution at EU and global level! Press Release 24/05/05. Zero Mercury Campaign.

European Environmental Bureau (EEB) et al. 2006a. Mercury export ban and storage of surplus mercury, letter sent to Commissioners 08/09/06. Brussels. Zero Mercury Campaign.

EEB et al. 2006b. Mercury rising: EU must press on with urgent mercury export ban. Press Release 08/09/06. Zero Mercury Campaign. 
Frances, J., Levacic, R., Mitchell, J. and Thompson, G. 1991. Introduction. In G. Thompson, J. Frances, R. Levacic, and J. Mitchell (eds) Markets, hierarchies and networks. London: Sage.

Grant, W., W. Paterson, and C. Whitston. 1988. Government and the chemical industry: a comparative study of Britain and West Germany. Oxford: Clarendon Press.

Greenpeace and EEB. 2003. Green groups call on Europe Commission to stop toxic trade in mercury. Press Release 29/03/03. Available at: <<http://www.ban.org/ban news/2004/040329 green groups.html >>. Last accessed $06 / 02 / 2014$

Hommels, A., T.M. Egyedi and E.Cleophas. 2012. Policy change and policy coherence: The case of competition versus public safety in standardization policies. Journal of European Integration. DOI: 10.1080/07036337.2012.711826.

Institute for European Environmental Policy 2006. Manual of Environmental Policy: The EU and Britain. London: Institute of European Environmental Policy.

Jordan A. and A. Lenschow. 2010. environmental policy integration: a state of the art review. Environmental Policy and Governance 20: 147-158.

Jordan, A. and A. Schout. 2006. The coordination of the European Union: exploring the capacities for networked governance. Oxford: Oxford University Press.

Jordan, G., and D. Halpin. 2006. The Political Costs of Policy Coherence: Constructing a Rural Policy for Scotland. Journal of Public Policy, 26 (1): 21- 41.

Kellow, A. and A.R. Zito. 2002. Steering through complexity: EU environmental regulation in the international context. Political Studies 50: 43-60.

Kassim, H. 2003a. Meeting the Demands of EU Membership: The Europeanization of National Administrative Systems. In K. Featherstone, and C. M. Radaelli (Eds.) The Politics of Europeanisation. Oxford: Oxford University Press. pp 83-111.

Kassim, H. 2003b. The European Administration: Between Europeanization and Domestication. In J. Hayward, and A. Menon (Eds.) Governing Europe. Oxford. Oxford University Press. pp 137- 161.

Kassim, H. 1994. Policy networks and European Union policy making: A sceptical view. West European Politics. 17 (4): 15-27.

Kellow, A. and A. R. Zito. 2002. Steering Through Complexity: EU Environmental Regulation in the International Context. Political Studies 50: 43-60.

Kickert, W.J.M., E.H. Klijn and J.F.M. Koppenjan. 1997a. Introduction: a management perspective on policy networks. In W.J.M. Kickert, E.H. Klijn, and J. F.M. Koppenjan (eds) Managing complex networks: strategies for the public sector. London: Sage, pp. 1-13.

Kickert, W.J.M., E.H. Klijn, E.H. and J. Koppenjan. 1997b. Managing Networks in the Public Sector: Findings and Reflectionsí In W. J. M. Kickert, E-H. Klijn, and J. F.M. Koppenjan (Eds.), Managing Complex Networks: Strategies for the Public Sector. London: Sage. Pp. 166-191.

Kohler-Koch, B. and R. Eising. 1999. The Transformation of Governance in the European Union. London: Routledge.

Kooimann, J. 2003. Governing as Governance. London: Sage.

Marsh, D. and Rhodes, R.A.W. 1992. Policy communities and issue networks: beyond typology. In D. Marsh and R.A.W. Rhodes (eds) Policy networks in British government. Oxford: Oxford University Press, 249-268.

Mazey, S., and J. Richardson. 1993. Lobbying in the European Community. Oxford: Oxford University Press.

Metcalfe, L. 1994. International policy coordination and public management reform. International Review of Administrative Sciences. 60, 271-290.

Metcalfe, L. 2000 Reforming the Commission: Will Organizational Efficiency Produce Effective Governance? Journal of Common Market Studies. 38: 817-841. 
Ministry of Environment Sweden. 2004. Letter sent to the European Commission. Important issues of the Mercury Strategy. 17 February 2004. Stockholm. Swedish Ministry of Environment.

Nilsson, M, T. Zamparutti, J.E. Peterson, B. Nykvist, P. Rudberg, and J. McGuinn. 2012. Understanding policy coherence: An analytical framework and examples of sectorenvironment policy interactions in the EU. Environmental Policy and Governance. DOI:10.1002/eet.1589.

Nordic Council 2004. Workshop on mercury-needs for further international environmental agreements. 29-30 March 2004. Brussels.

Perri, 6., D. Leat, K. Seltyer, and G. Stoker 2002. Towards holistic governance. London: Plagrave.

Peters, B.G. 2013. Towards policy coordination: alternatives to hierarchy. Policy and Politics 41 (4): 569-84.

Peters, B.G. 1998. Managing horizontal government: the politics of coordination. Public Administration 76: 295-311.

Peters, B.G. 2003. The capacity to coordinate. Paper presented at workshop on 'Coordinating the EU: constructing policy coordination and coherent action in multi-level system'. Birkbeck College. December 2003. University of London.

Peters, G. and J. Pierre 2003. Handbook of public administration. London: Sage.

Peterson, J. 2004. Policy Networks. In A. Wiener, and T. Diez (Eds.), European Integration Theory. 117-135. Oxford: Oxford University Press.

Peterson, J. 1995. Policy Networks and European Union Policy Making: a Reply to Kassim. West European Politics. 18 (2): 389-407.

Peterson, J. and E. Blomberg 1999. Decision-making in the European Union. Basingstoke: Palgrave Macmillan.

Pierre, J. and B.G. Peters. 2000. Governance, politics and the state. London: Macmillan.

Peters, J. and V. Wright. 2001. The national coordination of European policy making. In J. Richardson (ed.) European Union: power, policy making (2e). London: Routledge.

Richardson, J. 1996. Policy-making in the EU: Interests, Ideas and Garbage Cans of Primeval Soup. In J. Richardson (Ed.), European Union: Power and Policy Making. London: Routledge. Pp. 3-23.

Rhodes, R.A.W. 1996, The New Governance: Governing Without Government. Political Studies. XLIV: 652-667.

Rhodes, R.A.W. 1997. From marketisation to diplomacy: it's the mix that matters. Australian Journal of Public Administration. 56(2): 40-58.

Sbragia, A. 2000. The European Union as coxswain. In J. Pierre (ed) Debating governance. Oxford: Oxford University Press. pp. 219-240.

Schön-Quinlivan, E. 2012. The European Commission. In A. Jordan and C. Adelle (eds) Environmental Policy in the EU (3e). London: Earthscan. pp. 95-112.

Schout, A. and J. Jordan. 2005. Coordinated European governance: Self-organising or centrally steered. Public Administration. 83 (1): 201-220.

Selin, N., and H. Selin. 2006. Global politics of mercury pollution: the need for multi-scale governance. RECIEL 15 (3), 258-269.

Slaughter, A.M. 2004. A New World Order. Princeton: Princeton University Press.

Smith, M.J. 1993. Pressure, Power and Policy. Hemel Hempsted. Harvester Wheatsheaf.

Swedish Environment Protection Agency. 2003. A safe mercury repository: a translation of the official report SOU 2001: 58. Report 8105 January 2003. Stockholm: Swedish EPA.

Thompson, G. F. 2003. Between hierarchies and markets: the logic and limits of network forms of organisation. Oxford: Oxford University Press.

UNECE. 2006. Convention on Long-range Trans-boundary Air Pollution $<$ http://www.unece.org/env/Irtap/Irtap h1.htm >> Last accessed 06/02/2014: UNECE.

UNEP. 2003. Global Mercury Assessment. Nairobi. UNEP. 
Wollmann, H. 2003. Coordination in the intergovernmental setting. In G. Peters and J. Pierre (eds). Handbook of Public Administration. London: Sage. pp 594-606.

\section{List of (referenced) interviews}

Interview 1, DG Environment, 20/11/06

Interview 2, DG Environment, 22/11/06

Interview 3, DG Enterprise, 14/11/06

Interview 7, Swedish Environmental Protection Agency, 14/12/06

Interview 8, Institute of Environmental Sciences, University of Leiden, the Netherlands, 01/12/06

Interview 9, Danish Environmental Protection Agency, 29/11/06

Interview 12, Mercury Policy Project, 27/11/06

Interview 14, EuroChlor, 13/12/06

Interview 15, Independent Consultant, 10/11/06 